\title{
Prevalence of Ectoparasites of Indigenous Chickens From Dalahu Region, Kermanshah Province, Iran
}

\section{İran’ın Kirmanşah İlinin Dalahu Bölgesinde, Yerli Tavuklarda Ektoparazitlerin Yaygınlığı}

\author{
Mohammad Mirzaei' ${ }^{1}$ Omid Ghashghaei ${ }^{1}$, Mohammad Yakhchali \\ 'Department of Pathobiology, Faculty of Veterinary Medicine, Shahid Bahonar University of Kerman, Kerman, Iran \\ ${ }^{2}$ Department of Pathobiology, Urmia University Faculty of Veterinary Medicine, Urmia, Iran
}

\section{ABSTRACT}

Objective: Ectoparasitism is an important factor associated with the poor production of indigenous chickens. The present study was undertaken to estimate the prevalence and ectoparasite diversity in indigenous chickens of the Dalahu region in the western part of Kermanshah province, Iran.

Methods: A total of 600 indigenous chickens (250 roosters and 350 hens) were randomly examined for the presence of different ectoparasites over the period April to September 2011. Ectoparasites were collected from different parts of chicken body using a hand lens, magnifying glass, and flashlights. The samples were preserved in $70 \%$ alcohol and cleared in lactophenol.

Results: The overall prevalence of ectoparasites was $52.8 \%$ ( $66 \%$ hens and $34.4 \%$ roosters) ( $p<0.001)$. Mixed infestation was noted in $70.34 \%$ of the chickens. The prevalence was significantly higher in young (66.3\%) animals compared with older animals (39.33\%) ( $p<0.001)$. Five species of ectoparasites were identified: Menopon gallinae (35.3\%), Menacanthus stramineus (26.7\%), Argas persicus (19\%), Dermanyssus gallinae (11\%), and Echidnophaga gallinacea (the "sticktight flea") (8\%).

Conclusion: The results of the present investigation reveal that ectoparasite infestation is prevalent in this area. Further studies are recommended to evaluate the effects of the ectoparasites on indigenous chicken health and production in the region (Turkiye Parazitol Derg 2016; 40: 13-6).

Keywords: Prevalence, ectoparasite, indigenous chickens, Dalahu, Iran

Received: 19.02 .2015

Accepted: 10.12 .2015

\section{ÖZ}

Amaç: Ektoparazitler yerli tavukların üretiminin azalmasına ilişkin önemli bir faktördür. Çalışma İran'ın batı bölgesinde yer alan Kermanşah ili Dalahu ilçesinde yerli tavuklarda Ektoparazitlerin prevalansını ve çeşitliliğini araştırmaktadır.

Yöntemler: Bu çalışmada 2011 yılı Nisan ile Eylül ayları içerisinde Dalahu yöresinde 600 adet yerli tavuk (250'si erkek ve 350'si dişi) olmak üzere toplanmış ve farklı ektoparazitlerin varlığı random olarak incelenmiştir. Ektoparazitler tavuk vücutlarının çeşitli kısımlarından Lenz, büyüteç ve flashlights kullanarak toplanmıştır. Örnekler \%70'lik alkolde saklanmış ve laktofenolde şeffaflaştırılmıstır.

Bulgular: Ektoparazitlerin toplam prevalensı \%52,8 (\%66,sı dişi tavuk ve \%34,4 horoz) saptanmıştır. Tavukların \%70,34 karışık enfeksiyonları vardır Genç tavuklarda prevalens anlamlı derecede yüksektir $(\% 66,33)$, ( $p<0.001)$. Tavuklardan beş tür ektoparazit izole edilmiştir; sırası ile Menopon galline (\%35,3), Menacanthus stramineus (\%26,7), Argas persicus (\%19), Dermanyssus gallinae (\%11), ve Echidnophaga gallinacea (the "sticktight flea") (\%8).

Sonuç: Bu araştırmanın sonuçları gösteriyor ki, ektoparazit enfeksiyon yaygınlığı çalışma bölgesinde yüksektir. İlave çalışmaların yapılması tavsiye edilip, ektoparazitlerin etkileri yerli tavukların sağlığı ve üretimi üzerinde analiz edilmelidir (Turkiye Parazitol Derg 2016; 40: 13-6).

Anahtar Kelimeler: prevalens, ektoparazit, yerli tavuk, Dalahu, İran

Geliş Tarihi: 19.02.2015

Kabul Tarihi: 10.12 .2015

Address for Correspondence / Yazışma Adresi: Dr. Mohammad Mirzaei E.mail: dr_mirzaie_mo@yahoo.com DOI: 10.5152/tpd.2016.4185

CCopyright 2016 Turkish Society for Parasitology - Available online at www.tparazitolderg.org

CTelif hakkı 2016 Türkiye Parazitoloji Derneği - Makale metnine www.tparazitolderg.org web sayfasından ulaşılabilir. 


\section{INTRODUCTION}

Indigenous chickens can be found in almost all households in rural areas. They are considered as an important source of income, besides providing a cheap source of protein in the form of meat and eggs to rural people $(1,2)$. Several species of ectoparasites (e.g., flies, lice, mites, and ticks) can infest poultry (3). Recently, a few studies were conducted on ectoparasites of indigenous chicken in Iran. Eslami et al. (4) reported seven species of ectoparasites in poultry in Golestan province, North Iran. Radfar et al. (5) found three species of ectoparasites in freerange backyard chickens in the Sistan region, Southeast Iran, where the animals were infested with Argas persicus (16.94\%), Menopen gallinae (55.93\%), and Menacanthus stramineus $(33.89 \%)(4,5)$. Yakhchali et al. (6) reported the prevalence of the poultry red mite (PMR) in layer farms in the Markazi province of Iran. Ectoparasites can be found practically in all birds, where they feed on their blood, feathers, skin, and scales. They may cause a range of symptoms, including discomfort, irritation, loss of plumage, stunted growth, reduced egg production and hatchability, anemia, increased feed costs, elevated mortality, and susceptibility to other infections (7-9). In addition, ectopara-

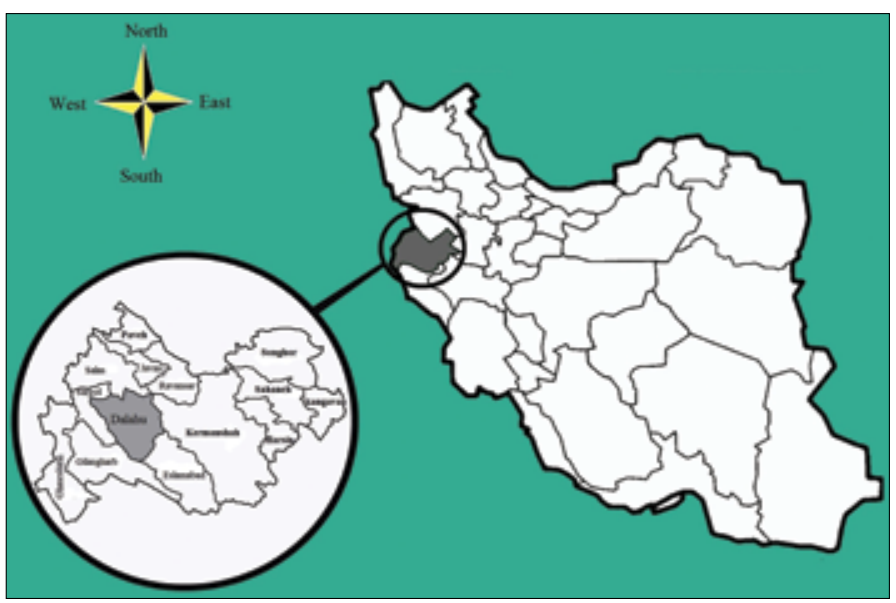

Figure 1. Map of sampling areas to investigate ectoparasites on the poultry of Dalahu region, Kermanshah province, Iran sites transmit several infectious diseases and serve as transport or intermediate hosts for different helminthic parasites (10-11). While lice generally feed on feathers, $M$. stramineus is known to feed on blood and to carry the equine encephalomyelitis virus. In contrast, Chlamydia psittaci, an intracellular bacterium causing psittacosis in birds, has been isolated from Menopon gallinae $(12,13)$. Furthermore, a number of other poultry diseases, such as pasteurellosis, fowl pox, Newcastle disease, and in some cases, Chlamydia, can be spread by some species of ectoparasites, especially ticks and mites (14). Dermanyssus gallinae has been widely reported to transmit human and animal pathogens (e.g., viruses and bacteria) and parasites (e.g., Hepatozoon) to farmers and veterinarians (15). Therefore, poor management of these parasites and limited accessibility to relevant resources prevent efficient poultry production through output reduction and the increasing risk of disease outbreaks $(16,17)$. Outbreaks of ectoparasites can be controlled using good management, control, and the treatment of poultry ectoparasites infestations. The aim of this study was to determine the prevalence and species diversity of ectoparasites in indigenous chickens in Dalahu region in western Iran. In addition, information from this study may be a guide to certain control measures, for instance, in the case of cross-infections, whereby the control of parasites in one host may help in eliminating the same parasite in another host.

\section{MATERIALS AND METHODS}

\section{Study area}

Dalahu county is located in Kermanshah province $\left(34^{\circ} 28^{\prime} \mathrm{N}\right.$ and $46^{\circ} 24^{\prime}$ E) (Fig. 1). Dalahu has a moderate and mountainous climate, with an annual rainfall of $541 \mathrm{~mm}$, a relatively humidity of $45 \%$, and an average annual temperature of $21.4^{\circ} \mathrm{C}$

\section{Samples and parasitological examination}

During the course of the study from April to September 2011, a total of 600 indigenous chickens were examined. At the beginning of the study, the number of all indigenous chickens and their sex (350 hens and 250 roosters) and age were recorded. They were divided into two groups, namely young and old (Table 1). The chickens were crossbred and fed with insects, grass seeds, and waste products in the environment, and occasionally their diets were supplemented with various grains.

Table 1. The prevalence of ectoparasites infestation based on age and sex in the examined poultry.

\begin{tabular}{|c|c|c|c|c|c|}
\hline Age & $\begin{array}{l}\text { No of examined } \\
\text { poultry }\end{array}$ & $\begin{array}{l}\text { No of infested } \\
\text { poultry }\end{array}$ & Prevalence (\%) & $95 \%{ }^{*} \mathrm{Cl}$ & **P value \\
\hline Young & 300 & 199 & 66.33 & $60.68-71.67$ & \multirow[t]{3}{*}{$P<0.001$} \\
\hline Old & 300 & 118 & 39.33 & $33.77-45.11$ & \\
\hline Total & 600 & 317 & 52.8 & $48.75-56.89$ & \\
\hline Sex & $\begin{array}{c}\text { No of examined } \\
\text { poultry }\end{array}$ & $\begin{array}{l}\text { No of infested } \\
\text { poultry }\end{array}$ & Prevalence (\%) & $95 \% * \mathrm{Cl}$ & **P value \\
\hline Female & 350 & 231 & 66 & 60.8-70.95 & \multirow[t]{3}{*}{$P<0.001$} \\
\hline Male & 250 & 86 & 34.4 & $28.5-40.6$ & \\
\hline Total & 600 & 317 & 52.8 & $48.75-56.89$ & \\
\hline
\end{tabular}


Table 2. Prevalence, predilection, and ectoparasite species diversity in the examined poultry.

\begin{tabular}{|l|c|c|c|}
\hline Ectoparasite Species & Common predilection site & No of infested birds & Prevalence (\%) \\
\hline Menopon gallinae & feather shafts and below wings & 112 & 35 \\
\hline Menacanthus stramineus & cloaca, thigh and breast region & 60 & 26.7 \\
\hline Argas persicus & ventral abdominal area and below wings & 35 & 19 \\
\hline Dermanyssus gallinae & cloaca, wings and Breast & 25 & 8 \\
\hline Echidnophaga gallinacea & comb, wattles and around the ears & & 81 \\
\hline
\end{tabular}

An aerosol $(\mathrm{ACl})$ was gently sprayed over the feathers and the ectoparasites were collected after 5 min by shaking the indigenous chickens. The vent, cloacae, breast, comb, wattles, and ear areas of the animals were inspected for fleas using a magnifying glass and/or flashlights $(5,18)$. To collect lice, the head, neck, wings, body surface, and cloacae were thoroughly examined using a magnifying glass. To detect infestation with poultry red mite (PRM), the animals were examined during the night hours (6). Finally, the ectoparasites were preserved in $70 \%$ alcohol, cleared in lactophenol, and mounted in Canada balsam on a slide. They were identified according to their morphological characteristics using key identification as described by Soulsby (19).

Statistical evaluation: A statistical analysis was undertaken using the Chi-square test .Data was analyzed by SPSS software, version 16 , and $p<0.05$ was accepted as statistically significant.

\section{RESULTS}

Overall, 317 (52.8\%) of the examined indigenous chickens were found to be infested with different species of ectoparasites. The highest infestation was found in young indigenous chickens (66.33\%, $\mathrm{p}<0.001)$. The infestation was significantly higher in hens $(66 \%)$ than in roosters $(34.4 \%)(p<0.001)$ (Table 1).

The most prevalent species was Menopon gallinae from the feather shafts and wings (35.3\%), followed by $M$. stramineus from the cloacae, thigh, and breast (26.7\%), A. persicus from the ventral abdominal areas and wings (19\%), D. gallinae from the cloaca, wings, and breast (11\%), and Echidnophaga gallinacea from the comb, wattles, and around the ears (8\%) (Table 2). There was mixed infestation in $70.34 \%$ with at least two species of ectopasites.

\section{DISCUSSION}

Poultry provide a valuable protein to the diets of people worldwide and is an important source of egg production (20). Many kinds and species of ectoparasites are known to infest chicken, e.g., flies, lice, mite, and ticks. Ectoparasites damage feathers and irritate and cause skin lesions, resulting in reduced performance of old chickens and direct harm to young chicks (10). Controlling ectoparasites in poultry flocks results in healthier and more economically productive birds for the pleasure and benefit of rural families (21). In the present study, the overall prevalence was moderate in examined indigenous chickens, and indeed, the prevalence of ectoparasites in indigenous chickens was slightly lower than that reported in other studies from different parts of the world, i.e., $95.8 \%$ in Kenya (22) and 88.4\% in China (23), while it was higher than that reported in Nigeria (41\%) (14) and Ethiopia (2.6\%) (24). The differences may be due to pesticide application, geographical distribution, climatic conditions, and management systems. In addition, it might be associated with the poor hygienic practice in rural regions, which creates a favorable environment for parasites and the free-range system, which provides a more sustainable environment for the parasites (22, $25,26)$. In this study, there were significant differences between prevalence in the different age groups of the examined indigenous chickens. This is not in accordance with other researches in Zimbabwe (2) and Nigeria (27), who reported that old indigenous chickens were more infested compared with younger ones. The result of this study indicates that young chickens could be more susceptible to parasitic infestation compared with old ones. This disparity among the findings might be due the variations in the study methods, geo-climatic condition of the research, immune response of the poultry to ectoparasitic infestation, implemented methods of disease control, and/or prevention and management systems applied $(2,22,25)$.

The infestation was significantly higher in hens. This is not in accordance with the work of Mungube et al. (26), who reported a higher occurrence of ectoparasites infestation in roosters (26); however, in Nigeria, hens had a higher infestation rate than roosters $(22,28)$. One of the reasons could be the stationary state of hens during the incubation of their eggs, which makes them more susceptible to parasitic infestations. In addition, roosters could transmit parasites during mating and the odor that hens emit during incubation may attract parasites $(22,28)$.

The species diversity and prevalence were similar to those previously reported in other studies $(2,4,5,14,29)$

From the results of this work, it can be concluded that further studies are needed to determine the direct and indirect economic losses of ectoparasite infestation in the region. Furthermore, the role of the ectoparasites on the outbreaks of concurrent parasitic infection as well as on bacterial and viral infections should be determined.

Ethics Committee Approval: Ethics Committee Approval was not needed for this study.

Informed Consent: Not required in this study.

Peer-review: Externally peer-reviewed.

Author contributions: Consept - M.M.; Design - M.M.; Supervision M.M.; Funding - M.M.; Materials - O.G.; Data Collection and/or Processing - O.G., M.Y.; Analysis and/or Interpretation - M.M., M.Y.; Literature Review - M.M., M.Y.; Writer - M.M.; Critical Review - M.M.

Conflict of Interest: The authors declare that they have no conflict of interest. 
Financial Disclosure: This study was financially supported by Shahid Bahonar University of Kerman.

Acknowledgments: The authors wish to thank Mr. Muslem Safari for his technical assistance and Professor K. Hazrati Tappeh and Dr. Hamid Tavangar for Turkish and English editing of this paper, respectively.

Etik Komite Onayı: Çalışmamız için etik komite onayı gerekmemiştir

Hasta Onamı: Çalışmamız için hasta onamı gerekmemiştir.

Hakem Değerlendirmesi: Dış Bağımsız.

Yazar Katkıları: Fikir - M.M.; Tasarım - M.M.; Denetleme - M.M.; Kaynaklar - M.M.; Malzemeler - O.G.; Veri Toplanması ve/veya ișlemesi O.G., M.Y.; Analiz ve/veya Yorum - M.M., M.Y.; Literatür taraması - M.M., M.Y.; Yazıyı Yazan - M.M.; Eleştirel Inceleme - M.M.

Çıkar Çatışması: Yazarlar çıkar çatışması bildirmemişlerdir.

Finansal Destek: Çalışmamız Shahid Bahonar University of Kerman tarafından desteklenmiştir.

\section{REFERENCES}

1. Magbool A, Ahmed M, Raza A. Prevalence of helminth parasites of poultry under different managemental conditions. J Fac Vet Med Univ Tehran 1998; 53: 103-10.

2. Permin A, Esmann J, Hoj C, Hove T, Mukaratirwa S. Ecto-, endo-and haemoparasites in free-range chickens in the Goromonzi District in Zimbabwe. Preventive Veterinary Medicine 2002; 54: 213-24. [CrossRef]

3. Winter AR, Funk EM. Poultry Science and Practice. 4th ed. Chicago, Philadelphia, New York: JB Lippincott Company; 1996.

4. Eslami A, Ghaemi P, Rahbari S. Parasitic infections of free-range chickens from Golestan Province, Iran. Iranian Journal of Parasitology 2009; 4: 10-14.

5. Radfar $\mathbf{M H}$, Khedri J, Adinehbeigi K, Nabavi R, Rahmani K. Prevalence of parasites and associated risk factors in domestic pigeons (Columba livia domestica) and free-range backyard chickens of Sistan region, east of Iran. Journal of Parasitic Diseases 2012; 36: 220-5. [CrossRef]

6. Yakhchali M, Rasouli S, Alborzi E. Prevalence and body distribution of the poultry red mite in layer farms from Markazi province of Iran. Iranian Journal of Veterinary Research 2013; 14: 72-4.

7. Campbell TW. Avian hematology and cytology. 2nd ed. lowa: lowa State University Press, Blackwell Publishing Company; 1995.

8. Edgar HB, Leslie EC, Pomeroy BS. Diseases and Parasites of Poultry. 5th ed. Philadelphia: Lea \&Febiger; 1958.

9. Strukie PD. Avian Physiology. 3rd ed. New York, Berlin: Springer Verlag; 1976. [CrossRef]

10. Arends JJ. External parasites and poultry pests. Diseases of poultry 2003; 11: 905-30.

11. Margaret LP. Diseases of Cages and Aviary Birds. 2nd ed. Philadelphia: Lea Febiger; 1969.

12. Calnek BW, Barness HJ, Bread CW, Reid WM, Yoder HW. Diseases of Poultry. 9th ed. lowa: lowa State University Press; 1991.
13. Kaufmann J. Parasitic infections of domestic animals: a diagnostic manual. Berlin: Basel; 1996. [CrossRef]

14. Nnadi P, George S. A cross-sectional survey on parasites of chickens in selected villages in the subhumid zones of South-Eastern Nigeria. J Parasitol Res 2010; 2010: pii: 141824

15. Valiente Moro C, De Luna CJ, Tod A, Guy JH, Sparagano OA, Zenner L. The poultry red mite (Dermanyssus gallinae): a potential vector of pathogenic agents. Experimental and Applied Acarology 2009; 48: 93-104. [CrossRef]

16. Dinka H, Chala R, Dawo F, Bekana E, Leta S. Major constraints and health management of village poultry production in rift valley of Oromia, Ethiopia. Am-Eurasian J Agric and Environ Sci 2010; 9: 529-33.

17. Halima H, Neser FW, Van Marle-Koster E, De Kock A. Village-based indigenous chicken production system in north-west Ethiopia. Tropical animal health and production 2007; 39: 189-97. [CrossRef]

18. Amede $Y$, Tilahun $K$, Bekele M. Prevalence of Ectoparasites in Haramaya University Intensive Poultry Farm. Global Veterinaria 2011; 7: 264-9.

19. Soulsby EJL. Helminths, Arthropods and Protozoa of Domestic Animals. 7th ed. Londonl, UK: Bailliere and Tindal; 1982.

20. Ensminger ME. Poultry Science. 1st ed. Danville, Illinois, USA: The interstate Printers and Publishers, Inc.; 1992.

21. Moyer BR, Drown DM, Clayton DH. Low humidity reduces ectoparasite pressure: implications for host life history evolution. Oikos 2002; 97: 223-8. [CrossRef]

22. Sabuni $Z$, Mbuthia P, Maingi N, Nyaga P, Njagi L, Bebora $L$, et al. Prevalence of ectoparasites infestation in indigenous free-ranging village chickens in different agro-ecological zones in Kenya. Livest. Res. Rural Dev 2010; 22: 1-5.

23. Wang FF, Wang M, Xu FR, Liang D, Pan BL. Survey of prevalence and control of ectoparasites in caged poultry in China. Vet Rec 2010; 167: 934-7. [CrossRef]

24. Tolossa YH, Tafesse HA. Occurrence of ectoparasites and gastro-intestinal helminthes infections in Fayoumi chickens (Gallus gallus Fayoumi) in Debre Zeit Agricultural Research Center Poultry Farm, Oromia region, Ethiopia. Journal of Veterinary Medicine and Animal Health 2013; 5: 107-12.

25. Mekuria S, Gezahegn E. Prevalence of External parasite of poultry in intensive and backyard chicken farm at Wolayta Soddo town Southern Ethiopia. Veterinary World 2010; 3: 533-8.

26. Mungube EO, Bauni SM, Tenhagen BA, Wamae LW, Nzioka SM, Muhammed $L$, et al. Prevalence of parasites of the local scavenging chickens in a selected semi-arid zone of Eastern Kenya. Trop Anim Health Prod 2008; 40: 101-9. [CrossRef]

27. Biu A, Agbede R, Peace P. Studies on ectoparasites of poultry in Maiduguri, Nigeria. Nigerian Journal of Parasitology 2008; 28: 69-72. [CrossRef]

28. Bala A, Anka S, Waziri A, Shehu H. Preliminary Survey of Ectoparasites Infesting Chickens (Gallus domesticus) in Four Areas of Sokoto Metropolis. Nigerian Journal of Basic and Applied Sciences 2011; 19: 173-80.

29. Banda Z. Ectoparasites of indigenous Malawi chickens. Australian Journal of Basic and Applied Sciences 2011; 5: 1454-60. 